Izvorni članak UDK 115(091)(38)"-07/04" doi: $10.21464 /$ fi36106 Primljeno 21. 10.2015.

\title{
Tonći Kokić
}

Sveučilište u Splitu, Filozofski fakultet, Sinjska 2, HR-21000 Split

tkokic@ffst.hr

\section{Predsokratski pojam vremena: moguće tumačenje}

\begin{abstract}
Sažetak
U ovom članku razmatraju se tri predsokratske koncepcije vremena, temeljene na Hesiodovom razmatranju pojma vremena $u$ Teogoniji, izvještajima o Talovom astronomskom radu i Parmenidovim teorijskim razmatranjima u poemi O prirodi. S obzirom na Aristotelovu

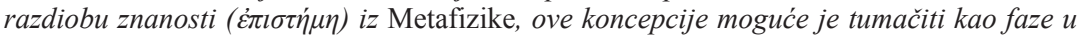

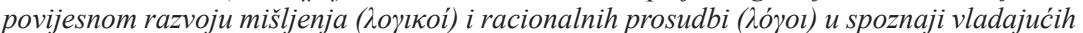
načela i zakona kozmosa: od Hesiodovog mitskog mišljenja koje je primitivna vrsta drevne

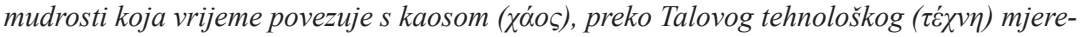
nja vremena ( $\chi \rho$ óvos) astronomskih fenomena radi praktične svrhe ili cilja, do Parmenidova čisto teorijskog (metafizičkog) promišljanja povezivanjem vremena s bićem u usmjerenoj spoznaji radi znanja samoga. Jedno moguće tumačenje odnosa ovih koncepcija može biti

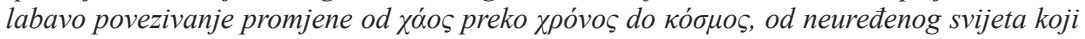
onemogućava racionalno snalaženje preko mjerenja kretanja vidljivih tijela do visoko teorijskog određenja bitka.
\end{abstract}

\section{Ključne riječi}

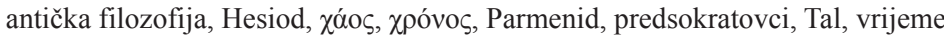

\section{Uvod}

Korijeni pitanja o postanku i naravi vremena, je li vrijeme stvoreno ili nije - ako jest, onda kada je, kako i iz čega stvoreno - što je eventualno bilo prije toga i koja je narav vremena - skriveni su u nedostupnim dubinama povijesti ljudske misli. Filozofsko određenje srži problema vremena nalazi se u Aristotela:

»Nakon stvari koje su rečene slijedi pozabaviti se vremenom. Prije svega je prikladno dvoumiti o njemu i s pomoću uobičajenih razloga: je li ono jedno od bića ili pak nebića, a zatim koja je njegova narav? Dakle, da ono postoji jedva i nejasno, mogao bi tkogod sumnjati na temelju slijedećega. Jer jedan je njegov dio bio i više nije, drugi će biti i još nije. A ipak se iz tih sastoji i beskonačno vrijeme i bilo koje uzeto vrijeme. Ono koje je složeno iz nebića čini se da ne bi moglo sudjelovati u bivstvu.« (Aristot. Phys. 217b29-218a3)

Prepoznavanje kontinuiteta u proučavanju problema vremena na Zapadu počinje prije Aristotela, već od pred-filozofskih mitskih pokušaja i pojave neposredno kasnije antičke filozofske misli. S posebnim interesom za istraživanje prikrivenih i neeksplicitnih početaka bavljenja vremenom u antici, zaobilaze se utjecajnija imena u ovom području i posvećuje se pažnja radovima autora iz čijih se djela neizravno mogu izvući elementi njihove koncepcije vremena. U ovom članku razmatraju se tri koncepcije vremena, temeljene na Hesiodovom 


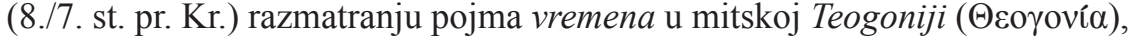
izvještajima o Talovom (6. st. pr. Kr.) mjerenju astronomskih fenomena i Parmenidovim (6./5. st. pr. Kr.) teorijskim razmatranjima u filozofskoj poemi $O$ prirodi. Svaka od ovih koncepcija vremena razmatra se u posebnom poglavlju, s pokušajem dokazivanja da je Hesiodova mitska koncepcija vremena

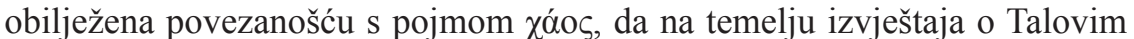

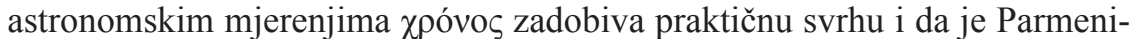
dova teorijska (metafizička) ideja poricanja vremena usko povezana s pojmom bića. Zaključak nudi moguće tumačenje prema kojem pojava ovih triju shvaćanja vremena, u razdoblju od svega 200 godina, predstavlja brzi razvoj

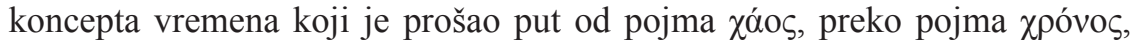

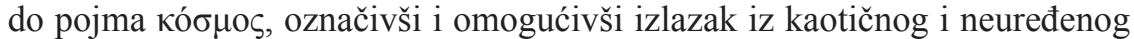
svijeta u kojem čovjek ne može bivati u svijet mjerljivog bivanja i dolaska do jednoznačno određenog fizičkog i metafizičkog svijeta koji predstavlja jedinu i pravu zbilju.

\section{Hesiod}

Svojom narativnošću, predfilozofska mitska objašnjenja svijeta također su vrsta mudrosti (Aristot. Met. 982b12-19), a Hesiodova opsežna poema Teogonija vjerojatno je jedna od prvih mitsko-poetskih reprezentacija svijeta i svakako jedino sačuvano djelo te vrste (Guthrie, 2005: 33). Neki tumači u Teogoniji ne vide mit nego prije filozofsku alegoriju (Graves, 2011). Unatoč poteškoćama prevođenja značenja pojmova s mitske simbolike u teorijske pojmove, ipak je moguće prepoznavanje i konstruktivno prenošenje značenja iz mitskog opisa rađanja bogova i njihove istovjetnosti s kozmičkim pojavama u teorijsku potragu za prvim počelom i nepromjenjivom osnovom svijeta. Objašnjenjem postanka i naravi kozmosa, teogonije postaju pred-filozofske kozmogonije i kozmologije koje već sadržavaju teorijski interes za opisom cjelovitosti zbilje, ali bez racionalne metode (Reale, 1987) i bez pravog po-

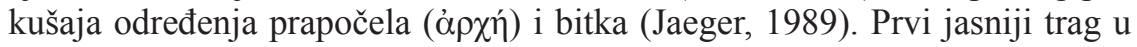
razumijevanju Hesiodove koncepcije vremena nalazi se u redoslijedu nastanka prvih triju božanstava, Kaosa (Xóos), Zemlje (Гаĩ $)$ i Erosa ('E $\rho \omega \varsigma)$ (Hes. Th. 116-120). Trag se može tumačiti kao uočavanje vremenske skale ili aspekata vremena gdje je »Uistinu Kaos prvi nastao« (Hes. Th. 116). Hesiod daje pregled geneze tadašnjeg reda Olimpljana pa se čini da je ovdje riječ o iskustvenom razlikovanju vremenskih aspekata prošlosti, sadašnjosti i budućnosti, koje uključuje »sadašnjost« kao referentnu točku (Bussanich, 1983) bez prepoznavanja teorijske mogućnosti (fizike) u kojoj nema takve privilegirane referentne točke (Denbigh, 1981). Vremenski slijed u opisu geneze može se činiti paradoksalnim s obzirom na praktičnu bezvremenitost (njem. Urzeit) mitskog vremena i ontološku statičnost takvog svijeta. Potraga za prvim načelom ne pretpostavlja njegov nastanak, makar, Aristotel piše kako Hesiod spominje da je Zemlja nastala prva, ali samo od tjelesnih stvari (Aristot. Met. 989a10-11) jer su Hesiodu Zeusova djeca sveta rasa vječnih besmrtnika (Hes. Th. 105-106). Zato ovdje treba razlikovati dva tipa stvaranja s njihovim ontološkim implikacijama: prvi je trenutačno stvaranje prvih bogova u primordijalnom trenutku u kojem nema trajanja, ali se ipak označava prošlošću; drugi tip stvaranja postanak je ostalih bogova u uobičajenom iskustvenom slijedu nastupanja iz prošlosti prema sadašnjosti. Iako Kaos postoji prije drugih stvari kao početna razina nadolazeće kozmičke akumulacije, bezvremenost nije istovjetna vječnosti. 
»Kaos označava granice kozmičkih procesa izvan kojih mitska reprezentacija ne može ići [...]. Kaos predstavlja bezdimenzionalnu ekspanziju kozmičke dubine u kojoj je započela njegova manifestacija.« (Bussanich, 1983: 214)

Kaos nije uzrok postanka bića te u sebi ne sadrži takvu mogućnost, on je prije bezvremenska ili vanvremenska utroba ${ }^{1}$ ili pasivni medij iz kojeg se mogu oblikovati svjetovi. Kaos predstavlja neodređenost u kojoj se ne razaznaju subjekti i objekti, a iz kojih može nastati sve ostalo, on je prvobitno jedinstvo koje prethodi vremenu (Sandywell, 2003). Usporedba izvornog i suvremenog razumijevanja pojma kaosa pokazuje mogućnost prevodivosti i očuvanja značenja već od sanskrtskog praizvora riječi kha koja u barem nekoliko od tridesetak značenja zahvaća sličnu misao (praznina, pukotina, rupa, prazan prostor, Brahma), preko grčkog značenja istog korijena khá(os) (opisanog u bilješci 1, iako ne i praznine) i latinskog značenja materia confusa, do suvremenog psihološkog značenja nesigurnosti, nemogućnosti orijentacije i brojnih drugih značenja u područjima kemije, termodinamike i teorije kaosa, usmjerenih označavanju nereda, nepravilnosti ili skrivenog reda. U Hesioda je kaos mišljen u teogonijskom smislu kao neodređeno »primordijalno stanje predkozmičke zbilje - zjapećeg ponora ili bezdana« (Bussanich, 1983: 214). Kaos označava kozmogonijsku granicu koja ne dopušta prelazak mitskom mišljenju iza nje, ali omogućava kakav-takav opis primordijalnog stanja. Hesiod nije izravno definirao pojmove kaosa i vremena, ali se iz citata »Uistinu Kaos je prvi nastao« (Hes. Th. 116) i »Kaos je porodio Ereba [tamu, nap. a.] i Noć« (Hes. Th. 123) opravdano može tumačiti da je kaos postojao prvi i prije svih ostalih stvari pa i vremena. Prema ovome se čini razložno smatrati da je u Hesiodovoj viziji vrijeme nastalo oblikovanjem iz kaosa zajedno ili usporedno s nastankom prvih stvari. Ovo tumačenje može se poduprijeti njegovim kasnijim regularnim slijedom izvođenja bogova sve do božica koje su porodile s muškarcima ljudske vrste (Hes. Th. 965-1020) i žena koje su porađale s bogovima (Hes. Th. 1020 ff.). Postanak stvari, prelazak iz nebivanja u bivanje predstavlja ontološki »kvantni skok«, ali je upitno može li se i u kojoj mjeri izjednačiti mitološko i filozofsko značenje postanka: za Bussanicha (1983: 214) se Hesiodov kaos može misliti tek kao pasivno načelo oblikovanja bogova i kozmosa, a ne pozitivno načelo »Oca koji je izvor«, koje spominje Platon u Timeju (Plat. Tim. 50d2). Tvorcima narativnih objašnjenja Aristotel ipak priznaje mudrost: »zbog toga je i ljubitelj priča donekle ljubitelj mudrosti [...] ako su se dakle bavili mudrošću kako bi izbjegli neznanje« (Aristot. Met. 982b18-20); a Hesiodu pripisuje potragu za uzrokom: »Hesiod veli [...] kao da u bićima mora biti prisutan neki uzrok « (Aristot. Met. 984b26-30); no ipak smješta njegove tvrdnje u drevne, pučke (Met. 989a11-13) ili mitološke

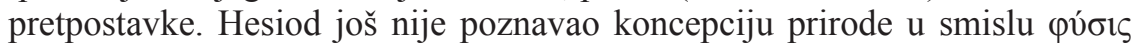
kao samostalnog područja (Bussanich, 1983), nego se oslanjao na mitološki (kozmogonijski) opis koji bogove čini počelima ili ih iz njih izvodi. Aristotel tako piše: »Hesiodovi sljedbenici i svi bogoslovi [grč. $\theta \varepsilon 0 \lambda o ́ \gamma o 1$, prvotni kozmolozi i tvorci mitske filozofije, nap. prev.] «(Aristot. Met. 1000a10). Hesiod nije izravno odredio narav i genezu vremena, ali se postanak vremena neizravno može povezati s »čahurom« kaosa iz koje je nastalo zajedno ili usporedno s drugim stvarima. Ovo tumačenje teško može izbjeći usporedbu s tumačenjima rasta i oblikovanja univerzuma i vremena (prostor-vremena)

Utroba, uterus, maternica: grč. $\mu \eta \dot{\tau} \tau \rho \alpha$, lat. $m a-$ trix, mater i eng. mother. Od brojnih mogućih tumačenja grč. pojma mêtra, ovdje bi najviše 
iz primordijalne točke beskonačne gustoće suvremene kozmološke Teorije velikog praska koja također pretpostavlja postanak vremena (Hawking, 1980: 149). Antički mit jasno je dao do znanja da je primordijalnog boga Nebo (Oủpavós) svrgnuo njegov sin, Otac vremena (Kрóvos).

\section{Tal}

Milećani, uključivši Tala, sasvim sigurno su svoju misao temeljili na mitskim kozmogonijskim opisima postanka svijeta, ali su onda preoblikovali njihovu kozmogoniju razmatranjem prapočela koje nadilazi svaku promjenu pomoću »fizičkog« nazora na svijet (Windelband, 1988). Aristotel je Hesioda i njegove sljedbenike smatrao bogoslovima jer su razmatrali pojedinačne uzroke pojedinačnih događaja i ono što je njima bilo vjerojatno (Aristot. Met. 1000a10), dok Tala (6. st. pr. Kr.) smatra začetnikom naravoslovaca ( ili $\varphi v \sigma 10 \lambda o ́ \gamma o \imath)$ koji su tragali za jedinstvenim tvarnim počelom svih stvari na svijetu (Aristot. Met. 983b6-20) pretpostavljajući zakonitost poretka brojnih zamršenih pojava, koja se može svesti na manji broj načela (Guthrie, 2005). Laerćanin navodi da je Tal "prvi dobio nadimak filozofa« (D. L. I, 22-5). Oslanjajući se na Aristotelovu ideju napredovanja u znanosti, Tala bi se moglo svrstati u napredniju skupinu jer, nakon početnog čuđenja očitim neobičnostima, dolaze oni koji su »napredujući pomalo stali dvojiti i o krupnijim stvarima, kao o mijenama Mjeseca, Sunca i zviježđa« (Aristot. Met. 982b13-16). Tal i jest poznat po proučavanju fenomena (i njihove povezanosti) gibanja Sunca, Mjeseca, zvijezda i izmjene godišnjih doba pomoću tradicionalne horizontalne astronomije, većinom promatranjem svitanja i sumraka (White, 2008). Svoju genijalnost dokazao je jednostavnim načinom »mjerenja visine piramida prema njihovoj sjeni, prateći kada je naša sjena iste dužine kao naše tijelo« (D. L. I, 27). Kako je miletska škola vukla korijene i od praktičnih znanja jonskih pomoraca koji su se u navigaciji oslanjali na sustavno proučavanje neba, moguće je da je zato Talu pripisano utemeljenje pomorske astrologije ili astronomije, iako drugi pišu da je to djelo Foka sa Sama, treći da je Tal još napisao i djelo $O$ kratkodnevici i ravnodnevici, a četvrti da nije napisao ništa (White, 2008). Također, pripisuje mu se prvenstvo u mjerenju konstelacije sazviježđa Malog medvjeda koje je pouzdanije u navigaciji od vidljivijeg Velikog medvjeda (White, 2008). Dvojbe oko autorstva proizlaze iz sumnje da je uopće išta napisao, kao i misterija »Kako su zabilježena prva izvješća o Talu i kako su dospjela Eudemu [Eudem s Roda, Aristotelov učenik, nap. a.]« (White, 2008: 91). Uz Eudema, izvještaji o Talovoj astronomiji nalaze se kod Herodota, Aristofana, Platona i Aristotela pa se čini mogućim u nekoj mjeri govoriti o njegovoj koncepciji (mjerenja) vremena iz perspektive zabilježenih studija proučavanja periodičkih astronomskih fenomena. Izvještaji navode njegovo prvenstvo u određenju kretanja Sunca između dvaju suncostaja, veličine Sunčevog kruga i Mjeseca (D. L. I, 25). Herodot piše da je tijekom jedne od brojnih bitaka u šestoj godini rata između Medijaca i Lidijaca nastupila noć za koju je Tal »Jonjanima predvidio godinu u kojoj se zaista dogodila te da je nakon toga sklopljen mir« (Hdt. 1.74.1-3). Suvremene matematičke tablice pomrčina smještaju taj događaj na dan 28. svibnja 585. god. pr. Kr. potvrđujući sam događaj, no tumači sumnjaju »da su Tal, Babilonci ili bilo tko drugi tada imali sredstva za takvo predviđanje« (Mosshammer, 1981: 146). Također, i zato što je po Herodotovom izvještaju Tal "predvidio godinu « (Hdt. 1.74.2), a ne točan datum i sat. Uzimajući u obzir da NASA, ${ }^{2}$ uz ovu šestominutnu potpunu pomrčinu, navodi datum 28 . svibnja 584. i određuje područje južnije od centralne Anatolije (rijeka Kizil), gdje je 
bila bitka Medijaca i Lidijaca, i iz kojeg pomrčina nije bila vidljiva, ${ }^{3}$ čini se opravdanim tvrditi da nije »postojala pomrčina Sunca koju Herodot opisuje i da je Talovo predviđanje izmišljeno« (Mosshammer, 1981: 151). Uzimajući u obzir ove argumente te prihvaćajući da je većina drevnih izvještaja o Talu legenda i da je već ranije bila poznata primitivna metoda određenja suncostaja horizontalnim praćenjem putanje Sunca, nema argumenata koji bi Talu mogli pripisati prvenstvo u otkriću ili predviđanju suncostaja. Jednostavnije je prihvatiti »da je otkrio godišnja doba i (godinu) podijelio na tristo šezdeset i pet dana « (DK A.11.27). ${ }^{4}$ Međutim, njegov napor u određenju vremenskih intervala između astronomskih pojava jasan je čin mjerenja oslonjen na koncept kronološkog vremena ( $\chi \rho o ́ v o \varsigma)$. Također, mjerenje vremena između pojava koje se pravilno ponavljaju »pod uvjetom da su te pojave zbilja periodične i da je mjerenje točno, osigurava pouzdanu osnovu za predviđanja« (White, 2008: 94) koja su pretpostavka znanosti. Tal je uočavanjem periodičkih događaja i njihovim mjerenjem objasnio uzvodno povlačenje Nila etezijskim vjetrovima (D. L. I, 37), a smisao mjerenja vremena i predviđanja budućih

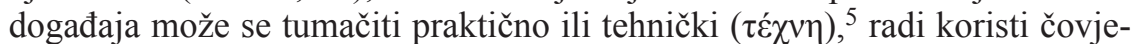
kovih poslova. Primjenjivost astronomskog znanja još je očitija, više nego za plovidbu, u priči o tome kako je, »saznavši pomoću astronomije da će masline dobro roditi«, zakupio zimi jeftino sve preše za ulje jer nije bilo drugih tražitelja i kasnije ih skupo iznajmljivao (Aristot. Pol. 1259a6-18; D. L. I, 26-27). Izvještaj, neovisno o njegovoj istinitosti, pa i u tom smislu da su već prije Tala poljoprivrednici koristili različite sezonske znakove kao vodiče u radovima $i$ zato što je poduhvat motiviran »željom da se pokaže kako je lako obogatiti se« (D. L. I, 27), očit je primjer tehnološkog poznavanja činjenica i njihove primjene. Aristotel u Drugoj analitici upravo na primjeru (Talove) pomorske astronomije dijeli dedukciju činjenica od razloga koji objašnjavaju zašto, na matematičke (teorijske) i empirijske (tehnološke) znanosti:

»Neke od tih znanosti imaju gotovo isto ime - na primjer matematička i pomorska astronomija [...]. Empirijski znanstvenici znaju činjenice, a matematički znanstvenici znaju razloge zašto su činjenice takve.« (Aristot. APo 79a2-5)

$\mathrm{Na}$ temelju iznesenog, mislim da je moguće tumačenje da je Talovo mjerenje astronomskih fenomena mjerenje vremena ( $\chi \rho$ óvo $_{\text {) }}$ kojemu se može pripisati praktična ili tehnološka $(\tau \dot{\varepsilon} \chi v \eta)$ svrha ili cilj. Koncept vremena u Tala se temeljio na pred-teorijskom povezivanju kretanja tijela i vremena.

\section{Parmenid}

Parmenidu se, slično kao i Talu, pripisuju astronomska otkrića jer »izgle-

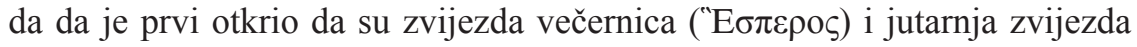

Astronomski opis i tablice pomrčine raspoložive su na mrežnim stranicama NASA-e: http://eclipse.gsfc.nasa.gov/SEsearch/SEsearchmap.php?Ecl=-05840528, http://eclipse. gsfc.nasa.gov/SEhistory/SEhistory.html\#0584 (pristupljeno 21. kolovoza 2015.).

Ova je pomrčina zato bila vidljiva iz područja gdje su danas gradovi Zadar (na sjevernom rubu putanje), Split i pogotovo Dubrovnik koji je smješten na mjestu koje je tada bilo blizu centra putanje pomrčine. No u to doba ondje nije bilo grčkih kolonija niti drugih urbanih sredina.

4

Fragmenti iz Dielsovih Predsokratovaca, citirani u ovom članku, preuzeti su iz hrvatskog prijevoda (Diels, 1983).

Izbjegavajući brojna značenja, ovdje se pod $\tau \varepsilon ́ \chi v \eta$ misli na znati kako, naspram $\theta \varepsilon \omega p i ́ \alpha u$ smislu znati što. 


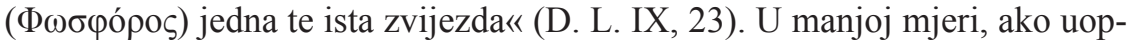
će, moglo bi mu se pripisati zahvaćanje vremena preko kretanja ili promjene bitka jer Parmenid nije nijekao samo ontološke prijelaze od nebitka $\mathrm{k}$ bitku i obratno, nego i »promjenu mjesta« (DK 28.B.41). Ovo Parmenidovo povezivanje bitka s vremenom, koje neizbježno podsjeća na ujedinjenje prostora i vremena specijalne teorije relativnosti kojom je dokinuta neovisnost ovih dvaju entiteta, primijetio je već Gödel te uvrstio Parmenida među one »koji su bili sumnjičavi prema ontološkoj stvarnosti vremena« (Yourgrau, 2006: 109). Čini se da su redci koji prethode gornjem citatu (DK 28.B.41) »najbolje mjesto za uvid u Parmenidovu koncepciju vremena« (Manchester, 2005: 106):

»Isto je misliti (kao) i ono o čemu se misli; nećeš, naime, bez bića u kojem je (to) izrečeno pronaći mišljenje: drugoga nema niti će biti ičega osim bića - okovala ga Moira nepokretno i cijelo da bude.« (DK 28.B.8.34-38)

Dramatiku ovom opisu bitka podižu Homerove riječi da je »Sudbina (Moira) okovala« zbilju učinivši je nepokretnom, bez mogućnosti kretanja ili gibanja, postanka i propadanja pa je zbilja jedinstvena, cjelovita i nepokretna. Iz ovoga slijedi da postanak i propadanje, koji dovode u vezu bitak i nebitak, te kretanje i prostor (i vrijeme), nisu zbiljski. Parmenidove tvrdnje »Isto je misliti (kao) i ono o čemu se misli« (DK 28.B.8.34) i »proturječna tvrdnja nije u skladu s istinom « (DK 28.B.6) upućuju na njegovo oslanjanje na načelo (ne)protuslovlja i snagu logičkog, racionalnog mišljenja koje ukazuje na protuslovna osjetilna zapažanja koja, ma koliko dojmljiva bila, ne mogu biti istinita. Uzimajući tako za načelo vodstva istinite misli a priori uvid, jer je takav put »onaj bezuvjetne istine« (Reale, 1987: 83), može se pretpostaviti da Parmenid »može označiti protuslovnim sva vjerovanja u zbiljnost onoga promjenjivog ili temporalnog, zaključujući da zbilja nije niti promjenjiva, niti temporalna « (Hoy, 1994: 574-575). Parmenid izrijekom ne spominje riječ $\chi \rho o ́ v o \varsigma$, ali očito je povezuje s bitkom (DK 28.B.8.5), ${ }^{6}$ niječući bivanje u prošlosti (niti je bilo) i budućnosti (niti će biti) i tvrdeći prisutnost bitka samo u sadašnjosti (čitavo sad je). ${ }^{7}$ Prema ovome, tvrdnje da bitak niti ima početka u vremenu, niti da će skončati u njemu (Manchester, 2005), predstavljaju nijekanje ontološke promjene koja bi nužno morala pretpostavljati postanak bitka iz nebitka (kao i prelazak bitka u nebitak) i bitak onoga što nije (DK 28.B.8.7-9). Negativno određeni vremenski pojmovi 'niti je bilo' i 'niti će biti', kao i pojmovi 'nastanka' i 'nestanka', mogu biti tumačeni kao puki nominalni pojmovi bez značenja ili »imena koja ljudi pogrešno koriste u pokušaju opisa zbilje« (Hoy, 1994: 581). Iz Parmenidove koncepcije vremena zato je moguće tvrditi samo da bitak jest sada - čitavo sad je (DK 28.B.8.5) - pretpostavljajući možda vremensku beskonačnost subjekta jer on ne može nastati iz ničega, niti u bilo koje vrijeme. Ako bitak jest sada, a ne može nastati niti propasti, kao jedino moguće tumačenje nudi se prezentistička pretpostavka da postoje samo trenutno temporalno prisutni predmeti. U prilog ovoj tezi ide izvorni tekst koji kaže da ono postojeće mora biti ograničeno »jer ima krajnju granicu, sa svih je strana konačno« (DK 28.B.8.42-43) pa se može misliti da je tako i iz vremenske perspektive. U izvorniku stoji riječ 'sada' (vũv) koja može, dakako, označavati neku referentnu točku koja dijeli vremenske aspekte prošlosti od budućnosti, ali može biti i "puka« oznaka logičkog odnosa koja ne označava neku konkretnu točku na vremenskoj crti, temporalnu lokaciju ili uzročni redoslijed. S druge strane, neki tumači smatraju da »vremenska točka na vremenskoj crti predstavlja vrijeme ne-bitka i da je sama ta crta ne-bitak vremena, dok je sada vrijeme bitka [...] koje označava 
izlazak iz vječnosti« (Manchester, 2005: 128), a moglo bi se i pomisliti da je riječ o nekoj vrsti eternalizma »vječnoga sada« (Hoy, 1994: 594). Čini se

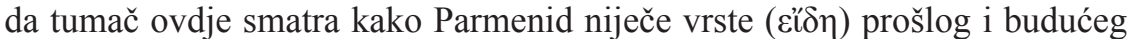
vremena, onoga što više nije i onoga što još nije, koje i Aristotel u uvodnom citatu (Aristot. Phys. 217b29-218a3) dovodi u pitanje kao slabe točke u prilog postojanja vremena, makar, piše da »sada utječe na prijelaz od noetičkog u osjetilno« (Manchester, 2005: 126). Može li se na osnovi bogatstva tumačenja reći da je bitak sada ili uvijek, da je nestvoreno ili da je prešlo iz nebivanja u bivanje u nekoj izvanvremenskoj stvarnosti? Prema ovom tumačenju, ono što jest mora biti cjelovito i ne smije sadržavati ontološku manjkavost da više nije ili da još nije, nego bitak i vrijeme moraju biti u granicama ( $\pi \varepsilon i ́ p \alpha \tau \alpha)$

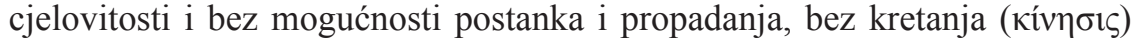
koje može značiti supstancijalnu promjenu ( $\mu \varepsilon \tau \alpha \beta$ o $\lambda \eta ́)$ prelaska u postojanje i izlaženje iz njega. Mislim da eventualna dvojba o mogućnosti shvaćanja koncepcije vremena kao isključivo misaonog alata, koji pomaže ljudskom umu u obuhvaćanju kretanja i promjene bitka, mora biti riješena Parmenidovim pripisivanjem identiteta mišljenja i bitka (DK 28.B.8.34). No misli li uopće Parmenid na zbiljnost vremena nije jasno: misao mora imati zbiljski predmet, tako da nije moguće umom nešto zahvatiti bez zahvaćanja postojanja tog nečega, a taj zbiljski predmet mora biti jedinstven, cjelovit, konačan i »nalik na masu lijepe okrugle kugle« (DK 28.B.8.43). Je li svijet, dakle, bezvremen ili je vrijeme zbiljsko, ali bezvremeno (eng. tenseless)? Parmenidove tvrdnje »niti je bilo niti će biti, čitavo sad je« (DK 28.B.8.5) niječu mogućnost bilo kakve temporalne distinkcije onome vječno postojećem i nepromjenjivom. $\mathrm{Na}$ kraju, ne može se drugačije tvrditi nego da za Parmenida kretanje, postanak i propadanje, koji dovode u vezu bitak i nebitak, te kretanje i prostor (i vrijeme), nisu zbiljski, a da njegova teorijska koncepcija vremena svojom atemporalnošću odriče osjetilnom iskustvu vremena zbiljnost koja je komprimirana u jedinstvenosti »čitavo sad je«. Parmenidova koncepcija vremena predstavlja dio visokorazvijenog teorijskog (metafizičkog) sustava otvorenog tumačenju.

\section{Zaključak}

Tri izabrane koncepcije vremena predsokratskih autora imaju obilježja koja se mogu protumačiti kao različite faze ili stupnjevi u napredovanju mišljenja s obzirom na Aristotelovu razdiobu znanosti. Antičko mišljenje čovje-

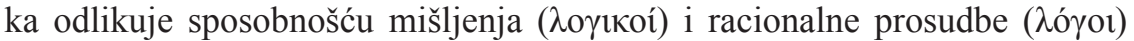

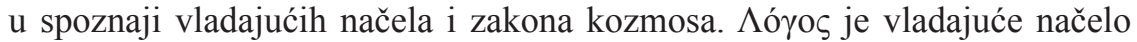
u čovjeka koje se u povijesnom razvoju uspinje od mitskog mišljenja, koje je primitivna vrsta drevne mudrosti, bez potrage za prvim počelima (Aristot. Met. 982b12-19; Aristot. Met. 989a11-13), preko bavljenja mudrošću radi praktične koristi (Aristot. Met. 982b21), do one konačne potrage za znanjem radi samoga znanja, koje je najviša znanost (Aristot. Met. 982a30-982b1).

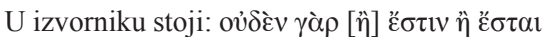

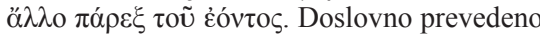
bilo bi to: Ništa jer [niti] je niti će biti drugo

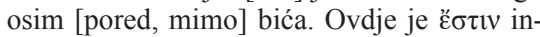
dikativ prezenta, a ह̌ $\sigma \tau \alpha$ je indikativ futura. Kako je već navedeno, u izvorniku nema riječi vrijeme, no taj bi se smisao mogao oslanjati

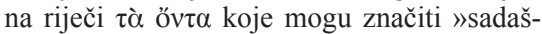
njost«, pa onda sadašnje »vrijeme« itd. Do-

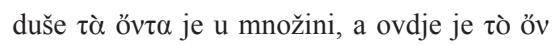
jednina i može značiti biće, bitak i bivanje.

7

Neki autori smatraju da je Platonovo određenje triju vremena kao triju vrsta vremena

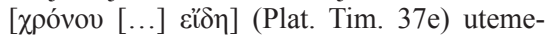
ljeno u Parmenidovom razdvajanju ovih vremenskih aspekata. 
Prema ovom obrascu, čini se da je moguće poredati razmatrane predsokratske koncepcije vremena. Prvi, Hesiodov koncept vremena konstruiran je iz

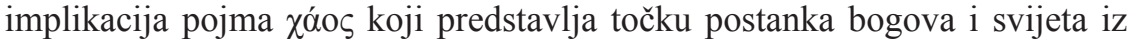
primordijalnog stanja iza kojega nije moguće spoznajno ići niti ga objasniti. Utjecaj Hesiodove koncepcije vremena može se pronaći u Platona (Plat. Tim. 38 b) za kojeg je vrijeme nastalo zajedno s nebesima iz kaosa i za koje bog preuzima neusklađeno kretanje i uređuje ga (Plat. Tim. 30a). Hesiod nije izravno odredio narav i genezu vremena, ali se neizravno može povezati postanak vremena iz »čahure« kaosa iz koje je nastalo zajedno ili usporedno s drugim stvarima, a konačno odrediti kao mitološku koncepciju povezanu s neodređenim i racionalno nespoznatljivim pojmom kaosa. Drugu, Talovu koncepciju vremena moguće je označiti praktičnim ili tehnološkim pristupom mjerenja

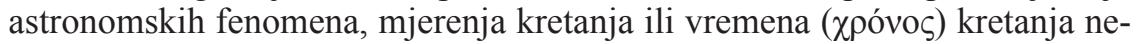
beskih tijela. Iz aspekta Aristotelove razdiobe znanosti, Talovo astronomsko znanje moglo bi imati obilježja tehnološkog poznavanja činjenica i njihove primjene radi koristi. Kako Aristotel piše, empirijske ili tehnološke znanosti obilježava poznavanje činjenica (Aristot. APo 79a2-5), no bez teorije koja bi objasnila zašto su činjenice takve kakve jesu. Treće, Parmenidovo promišljanje vremena povezuje vrijeme i bitak niječući kretanje, postanak i propadanje. Parmenid tako izgrađuje atemporalni koncept vremena koji priznaje osjetilno iskustvo vremena i kretanja, ali teorijski pobija njihovu zbiljnost. Oslanjajući se na Aristotelov obrazac razdiobe znanosti, Parmenidov koncept vremena spada u motriteljsku znanost usmjerenu spoznaji radi znanja samoga (Aristot. Met. 982a30-982b1), pa je tako najviši stupanj u napredovanju sposobnosti ljudskog mišljenja u spoznaji vladajućih načela i zakona kozmosa.

Prema ovome, moguće je tumačenje da pregledane koncepcije vremena predsokratskih autora predstavljaju brzo povijesno napredovanje u spoznaji pojma vremena u razdoblju od svega dva stoljeća. U ovom periodu koncept vremena se preoblikovao od povezanosti s pojmom $\chi \alpha$ ós, preko pojma $\chi \rho o ́ v o \varsigma$,

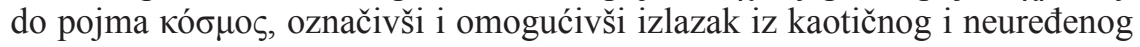

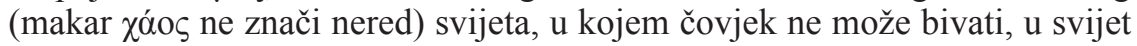

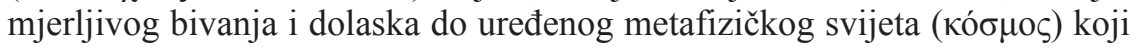
objašnjava zašto je svijet takav kakav jest.

\section{Literatura}

Aristotel. 1988. Fizika. Sveučilišna naklada Liber, Zagreb.

Aristotel. 1985. Metafizika. Sveučilišna naklada Liber i Globus, Zagreb.

Aristotel. 1975. Politika. Beogradski izdavačko-grafički zavod, Beograd.

Aristotle. 1984. »Posterior Analytics«. U: Barnes, J. (ur.) The Complete Works of Aristotle, str. 114-167. Vol 1. Princeton University Press, Princeton.

Bussanich, J. 1983. »A Theoretical Interpretation of Hesiod's Chaos«. Classical Philology, god. 78, br. 3, str. 212-219. doi: http://dx.doi.org/10.1086/366783.

Denbigh, K. 1981. Three Concepts of Time. Springer-Verlag, Berlin, Heidelberg. doi: http://dx.doi.org/10.1007/978-3-642-68082-3.

Diels, H. 1983. Predsokratovci. Fragmenti. Svezak I. Naprijed, Zagreb.

Graves, R. 2011. The Greek Myths: The Complete and Definitive Edition. Penguin Books, London.

Guthrie, W. K. C. 2005. Povijest grčke filozofije. Raniji predsokratovci i pitagorovci. Knjiga I. Naklada Jurčić, Zagreb.

Hawking, S. 1980. »Theoretical Advances in General Relativity«. U: Woolf, H. (ur.), Some Strangeness in the Proportion. Addison-Wesley, Massachusetts, MA. 
Hesiod. 1914. »Theogony«. U: Hesiod, The Homeric Hymns, and Homerica. Harvard University Press, Cambridge, MA., William Heinemann Ltd., London.

Hoy, R. 1994. »Parmenides' Complete Rejection of Time«. The Journal of Philosophy, god. 91, br. 11, str. 573-598. doi: http://dx.doi.org/10.2307/2941069.

Jaeger, W. 1989. Paideia: The Ideals of Greek Culture: Volume II: In Search of the Divine Centre. Oxford University Press, Oxford.

Manchester, P. 2005. The Syntax of Time: The Phenomenology of Time in Greek Physics and Speculative Logic from Iamblichus to Anaximander. Brill, Leiden i Boston.

Mosshammer, A. 1981. »Thales' Eclipse«. Transactions of the American Philological Association, god. 11, str. 145-155. doi: http://dx.doi.org/10.2307/284125.

Plato. 1925. »Timaeus«. U: Plato. Plato in Twelve Volumes, Vol. 9. Harvard University Press, Cambridge, MA., William Heinemann Ltd., London.

Reale, G. 1987. A History of Ancient Philosophy I. From the Origins to Socrates. State University of New York Press, New York.

Sandywell, B. 2003. The Beginnings of European Theorizing: Reflexivity in the Archaic Age. Routledge, New York. doi: http://dx.doi.org/10.4324/9780203424797.

Yourgrau, P. 2006. A World Without Time: The Forgotten Legacy of Gödel and Einstein. Basic Books, Cambridge, MA.

\title{
Tonći Kokić
}

\section{The Concept of Time in Presocratics: A Probable Interpretation}

\begin{abstract}
This article considers three Presocratic conceptions of time based on: Hesiod's consideration of time concept in Theogony, reports on Thales astronomical work and Parmenides' theoretical

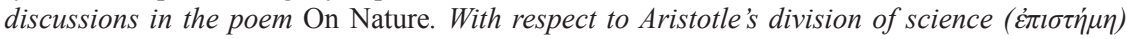
presented in Metaphysics, it is possible to interpret these conceptions as phases in historical

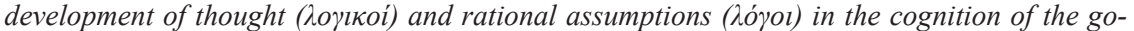
verning principles and laws of the cosmos: from Hesiod's mythical thought, a primitive type of an ancient wisdom that linked the time to the chaos ( $\chi \alpha$ os), across Thales'technological ( $\tau \dot{\varepsilon} \chi v \eta)$

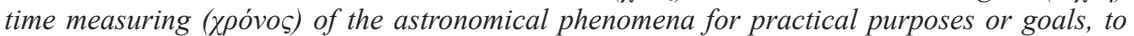
Parmenides' theoretical (methaphysical) deliberations that linked the time to the being, in orientation to cognition for the purpose of knowledge itself. One possible explanation for the re-

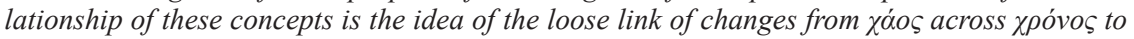
$\kappa o ́ \sigma \mu \varsigma$, , that is, from unarranged world, which prevents rational managing, over measuring the movements of visible bodies, to the highly theoretical definition of being.
\end{abstract}

\section{Key words}

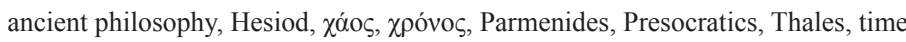

